ZOOLOGIA 30 (2): 200-210, April, 2013

http://dx.doi.org/10.1590/S1984-46702013000200010

\title{
Species composition and temporal activity of Arctiinae (Lepidoptera: Erebidae) in two cerrado vegetation types
}

\author{
Scheila Scherrer ${ }^{1}$, Viviane G. Ferro ${ }^{2,4}$, Marina N. Ramos ${ }^{1}$ \& Ivone R. Diniz ${ }^{3}$ \\ ${ }_{1}$ Programa de Pós-graduação em Ecologia, Instituto de Ciências Biológicas, Universidade de Brasília. 70910-900 Brasília, \\ DF, Brazil. \\ 2 Departamento de Ecologia, Instituto de Ciências Biológicas, Universidade Federal de Goiás. 74001-970 Goiânia, GO, Brazil. \\ ${ }_{3}^{3}$ Departamento de Zoologia, Instituto de Ciências Biológicas, Universidade de Brasília. 70910-900 Brasília, DF, Brazil. \\ E-mail:irdiniz@unb.br \\ ${ }^{4}$ Corresponding author. E-mail: vgferro@yahoo.com
}

\begin{abstract}
Arctiinae moths include nearly 11,000 species worldwide, of which approximately 700 species occur in the Brazilian Cerrado. The aim of this study was to describe the species composition of Arctiinae, as well as the variation in annual and nightly moth activity, in two Cerrado vegetation types. We sampled moths one night per month from September 2008 to June 2009, in the gallery forest and in the cerrado sensu stricto in the Jardim Botânico de Brasília. We collected 395 tiger moths belonging to 65 morphospecies; $74 \%$ of the species belonged to the tribe Arctiini and $26 \%$ to Lithosiini. Thirty-one species (47.7\%) occurred only in the gallery forest, 13 (20\%) occurred only in the cerrado sensu stricto, and 21 (32.3\%) occurred in both vegetation types. Additionally, we found the greatest species richness between 7:00 p.m. and 8:00 p.m., and these hours were associated with 21 and 22 species, respectively. Most species (51.8\%) were active for up to three hours during the night. In general, the species composition differed between the dry and rainy seasons, and the similarity of the fauna also varied hourly. Based on our results, we suggest that rapid inventories of Arctiinae be performed in both rainy and dry seasons, and sampling should be carried out the entire night.
\end{abstract}

KEY WORDS. Cerrado sensu stricto; gallery forest; moths; seasonality; time of activity.

Species richness and abundance vary in time and space. Several factors may influence this variation, including the climate; the formation or rupture of geographical barriers; human activities (e.g., deforestation, fire, and introduction of exotic species); the characteristics of the species (e.g., dispersal and reproductive capability); habitat structural complexity; the availability, amount, or quality of resources; and interspecific interactions (Silveira Neto et al. 1995, Dyer et al. 2007, Novotny et al. 2007).

Some studies have shown that, in regions with a seasonal climate, the abundance and activity of insects and other arthropods are related to climatic variables. For example, the abundance of several insect orders and spiders peak during the rainy season in the Caatinga and Cerrado Brazilian biomes (Pinheiro et al. 2002, Oliveira \& Frizzas 2008, Mineo et al. 2010, VASCONCEllos et al. 2010). Insect orders and families respond differently to temporal variations in the Cerrado, as do immature and adult insects. The abundance of species of Coleoptera, Hymenoptera, and Isoptera is related to temperature variation and is greater in the early rainy season (SiLva et al. 2011). Similarly, the greatest abundance of Cecidomyiidae (Diptera) gall midges occurs in the early rainy season (ARAújo \& SANTOS 2009).
The distribution of food resources and climate predictability (dry and rainy seasons) in the Cerrado may partially explain these variations, as suggested by WoLDA (1988) for tropical insects.

Adult lepidopterans in the Cerrado are evenly distributed throughout the year, but with a peak abundance in the early rainy season (Pinheiro et al. 2002, Oliveira \& Frizzas 2008), while caterpillars are most abundant in the first half of the dry season (Morais et al. 1999). The richness and abundance of species of several families of Lepidoptera vary throughout the year as well as among sites, habitats, and biomes. The Sphingidae from the Atlantic Forest do not vary seasonally (DUARTE JÚNIOR $\&$ Schlindwein 2005). However, the occurrence of species of Sphingidae from the Caatinga (GusMão \& CREÃo-DuARTE 2004) and the Cerrado (Амоrim et al. 2009) has been found to be markedly seasonal, and their population fluctuations are correlated with rainfall. In one forest in southern Ecuador, the abundance of Arctiinae has been found to not vary seasonally (Hilt et al. 2007), whereas abundance and richness peaks of Arctiinae species in Altamira (state of Pará, Brazil), an anthropized site of the Amazon rainforest, happen in June and July, during the less rainy period (Teston \& Delfina 2010). 
Studies on the temporal scale of diversity are important in helping us understand the stability of communities, and to predict the responses of organisms to environmental changes, as well as providing information for pest management and control. Studies addressing the temporal variation of species richness are rarer than those addressing spatial variation. Some reasons for this discrepancy may be the time required for the former type of research and the higher financial cost it involves. However, there has been an increase in funding for the development of long-term ecological research (LTER) both in Brazil and abroad, especially in the last two decades (Sousa et al. 2007, Araújo et al. 2010).

Insects are considered good models for temporal activity studies due to their short life cycles and rapid response to environmental changes. In addition, the abundance of insects can vary over the long (between years) and short terms (e.g., weeks; Wolda 1978, Cook \& Graham 1996). Moths have been used worldwide as model organisms for diversity studies (Silveira Neto et al. 1995, Camargo 1999, Kitching et al. 2000, Schwartz \& Mare 2001, Bеск et al. 2002, BRehm et al. 2003, Teston \& Corseuil 2004, Hilt \& Fiedler 2005, Sinvonen \& Silijander 2005, Specht et al. 2005, AXмACHer et al. 2009), and are considered to be good indicators of species richness and habitat disturbances (SumMERVILle et al. 2004).

Little is known about temporal patterns of insect richness and abundance in the Cerrado, and how biotic and abiotic factors influence the seasonal distribution of this group (PINHEIRo et al. 2002, Oliveira \& Frizzas 2008). However, it is known that the mean monthly temperature is significantly related to the distribution of lepidopteran populations (Oliveira \& Frizzas 2008). Studies addressing the daily activity of insects are also rare. In this study, we used moths of the subfamily Arctiinae (Lepidoptera: Erebidae) as model organisms. Arctiinae is a good model for understanding the mechanisms determining the diversity of tropical insects. These moths are highly diverse, easily sampled, have a relatively well-resolved taxonomy, and have already been studied in the tropics (e.g., Ferro \& Diniz 2007, 2010, Hilt et al. 2007, Ferro et al. 2010). Despite the high diversity of Arctiinae in the Cerrado (Ferro \& Diniz 2007, 2010), little is known about the natural history and behavior of the species in this group. The goal of this study was to assess how the species richness, abundance, and composition of Arctiinae vary annually and throughout the night in two Cerrado vegetation types (gallery forest and cerrado sensu stricto).

\section{MATERIAL AND METHODS}

Night-time sample collecting was performed in the Reserva Ecológica do Jardim Botânico de Brasília (1552'21"S, $\left.47^{\circ} 50^{\prime} 50 " \mathrm{~W}\right)$, approximately $6 \mathrm{~km}$ from downtown Brasília, the capital of Brazil (SAmbuichi \& Eiten 2000). The Reserva Ecológica do Jardim Botânico de Brasília (hereafter, Jardim Botânico de Brasília) is part of an environmental preservation area called
Cabeça de Veado (Fonseca \& Silva Júnior 2004) in the Cerrado biome (RATTER et al. 1997).

Sampling was performed during one year, from September 2008 to August 2009, in two Cerrado vegetation types: gallery forest and cerrado sensu stricto. Moths were sampled one night per month in each vegetation type (always in new moon nights). The period between October and March was considered the rainy season, and the dry season was between April and September (following RAtTer et al. 1997). Moths were collected from 7:00 pm to 5:00 am using a light source (mercuryvapor lamp $250 \mathrm{~W}$ ) hanging at $1.6 \mathrm{~m}$ reflected on a white sheet. All tiger moths were collected, killed in jars containing ammonium hydroxide, and separated into plastic vials labeled with the date and time. Individuals were measured, mounted, labeled, and identified by comparison to reference collections and with the aid of taxonomists. The moths were deposited in the Coleção Entomológica do Departamento de Zoologia da Universidade de Brasília (UnB 041581-041976).

The Shannon-Wiener diversity index, Simpson dominance index, and Chao 2 and Jackknife 1 richness estimators were calculated. A circular analysis (Rayleigh test) (ZAR 1996) was performed to test for concentrated peaks of abundance and richness throughout the year or night. A cluster analysis was performed using UPGMA (the unweighted pair-group method using arithmetic averages) with the Simpson index as a distance measure to evaluate the similarity between months and hours. All tests were performed for each vegetation type, for each hour of the night, and for all species. Circular analysis was performed using Oriana 3 software (Kovach Computing SERVICES 2011), and the remaining analyses were performed using PAST (HAMMER et al. 2007).

\section{RESULTS}

Overall, we collected 395 tiger moths belonging to 65 morphospecies, of which $69.2 \%$ were identified to species (Table I). Seventy-four percent of the identified species $(n=45)$ belonged to the tribe Arctiini and 26\% $(n=16)$ to Lithosiini. Five species represented new records for the Distrito Federal: Dolichesia rufa Schaus 1899, Hyperthaema signata (Walker, 1862), Lamprostola hercyna Druce 1885, Nodozana coresa Schaus 1896, and Thrinacia temenus (Stoll, 1781). The last two species were also the first records for the Cerrado. Singletons (species represented by one individual) accounted for $38.5 \%(n=25)$ of the species recorded. The observed richness was $62.7 \%$ to $68.6 \%$ of the estimated richness (Chao $2=103.7$ and Jackknife $1=93.4$ ).

The most abundant species was Parablavia sadima (Schaus, 1896) ( $\mathrm{n}=67)$. This species was restricted to the cerrado sensu stricto and represented $28 \%$ of the individuals sampled in this vegetation type. Other abundant species included Dycladia lucetius (Stoll, 1781) ( $\mathrm{n}=39$ individuals), Pareuchaetes aurata (Butler, 1875) ( $\mathrm{n}=37)$, and Lamprostola sp. $(\mathrm{n}=31)$. These three species occurred in both vegetation types. 
A total of 155 individuals from 52 species were found in the gallery forest, and 240 individuals from 34 species were found in the cerrado sensu stricto. Based on nonparametric estimators, approximately 14 more species were expected to occur in the cerrado sensu stricto (Chao $2=47.7$ and Jackknife $1=$ 48.6), while between 30 and 48 more species were expected in the gallery forest (Chao $2=100.4$ and Jackknife $1=82.2$ ). The gallery forest was associated with a higher Shannon-Wiener index (3.408) than the cerrado sensu stricto (2.627). The gallery forest presented a smaller Simpson dominance index (0.051) than the cerrado sensu stricto (0.127). Singletons were more common in the gallery forest $(\mathrm{n}=29)$ than in the cerrado sensu stricto $(n=12)$. Thirty-one species $(47.7 \%)$ occurred only in the gallery forest, 13 (20\%) occurred only in the cerrado sensu stricto, and 21 (32.3\%) occurred in both vegetation types (Table I).

\section{Species richness and abundance throughout the year}

Of the 65 species sampled, 25 (38\%) occurred year-round, 20 (31\%) occurred only in the rainy season (October to March), and another 20 were observed only in the dry season (April to September). Species richness (45) did not differ between the dry and rainy seasons, but species abundance was higher in the dry (223) than in the rainy season (172).

Species richness and abundance were similar between the two seasons (32 species and 78 individuals in the rainy season, 34 species and 77 individuals in the dry season) in the gallery forest. Species richness was also similar between seasons (20 species in the dry and 21 in the rainy season) in the cerrado sensu stricto; however, abundance was higher in the dry season (146) than in the rainy season (94).

Table I. Activity of Arctiinae species throughout the year in the Jardim Botânico de Brasilia. The numbers represent months from 1 (January) to 12 (December). The dry season is between April and September, and the rainy season is from October to March. * Indicates species restricted to the gallery forest; $\dagger$ indicates species restricted to the cerrado sensu stricto; species with no symbol occur in both vegetation types; species in bold are new records for the Cerrado.

\begin{tabular}{|c|c|c|c|c|c|c|c|c|c|c|c|c|c|}
\hline \multirow{2}{*}{ Species } & \multicolumn{13}{|c|}{ Total and monthly abundance } \\
\hline & 1 & 2 & 3 & 4 & 5 & 6 & 7 & 8 & 9 & 10 & 11 & 12 & Total \\
\hline \multicolumn{14}{|l|}{ Arctiini } \\
\hline Aclytia heber (Cramer, 1780) & & 4 & 1 & 1 & 4 & & 2 & & & & 2 & 1 & 15 \\
\hline Agaraea uniformis (Hampson, 1898) & & & & & & 1 & 1 & & & & 1 & & 3 \\
\hline Argyroeides braco (Herrich-Schäffer, [1855]) * & & & & & & & & 1 & & & & & 1 \\
\hline Ammalo helops (Cramer, 1775) & & & & & & & 1 & & & 1 & & 1 & 3 \\
\hline Cosmosoma achemon (Fabricius, 1798) & & & & & 1 & & & & & & 3 & & 4 \\
\hline Cosmosoma cruenta (Petry, 1834) $\dagger$ & & & & & 1 & 1 & & & & & & & 2 \\
\hline Cosmosoma restrictum Butler, 1876 & & & & & & & & & & & 1 & 1 & 2 \\
\hline Cresera affinis (Rothschild, 1909) * & 5 & 1 & 1 & & & 1 & & & & 3 & 2 & & 13 \\
\hline Dycladia lucetius (Stoll, 1781) & 2 & 2 & 2 & 2 & 2 & 2 & 5 & 5 & & 1 & 8 & 8 & 39 \\
\hline Dysschema hypoxantha Hubner, 1818 & 1 & & & & & & & & & & & & 1 \\
\hline Echeta minerva (Schaus, 1915) * & & & & & & & 1 & & & & & & 1 \\
\hline Elysius joiceye Talbot, $1928 \dagger$ & & & & & & & & & & 1 & & & 1 \\
\hline Elysius pyrosticta Hampson, 1905 * & 1 & & & & & & & & & & & & 1 \\
\hline Eucereon chalcodon Druce, $1893 \dagger$ & & & & & & & & & & & 1 & 1 & 2 \\
\hline Heliura tetragramma (Walker, 1854) & 1 & & & & 1 & & & & & & 1 & & 3 \\
\hline Hypercompe sp. 1 * & & & & & & & & & & 1 & & & 1 \\
\hline Hypercompe sp. 2 * & & & & & 1 & & & & & & & & 1 \\
\hline Hyperthaema signata (Walker, 1862) * & & & & & & & & 1 & & & & & 1 \\
\hline Hyperthaema sp. 1 & 1 & & & 1 & & & & & & & & & 2 \\
\hline Idalus citrinus Druce, 1890 & & & & 2 & & & & 2 & & & & & 4 \\
\hline Idalus lineosus Walker, 1869 & & & & & 4 & 2 & 1 & 1 & & & 1 & & 9 \\
\hline Leucanopsis rosetta (Schaus, 1896) & 1 & 5 & & & & & & & & 9 & & & 15 \\
\hline Leucanopsis sp. 1 * & & & & & & & & & & & 1 & & 1 \\
\hline
\end{tabular}


Table I. Continued.

\begin{tabular}{|c|c|c|c|c|c|c|c|c|c|c|c|c|c|}
\hline \multirow{2}{*}{ Species } & \multicolumn{13}{|c|}{ Total and monthly abundance } \\
\hline & 1 & 2 & 3 & 4 & 5 & 6 & 7 & 8 & 9 & 10 & 11 & 12 & Total \\
\hline Leucanopsis sp. 2 * & & & & & & & & & & 1 & & & 1 \\
\hline Leucanopsis sp. 3 * & & & & 1 & & & & & & & & & 1 \\
\hline Lophocampa citrina (Sepp, 1852) † & & & 1 & 1 & 2 & & & & & & & 2 & 6 \\
\hline Lophocampa sp. & & & & & 2 & & & & & & & & 2 \\
\hline Macrocneme sp. * & & & & & & & & 1 & & & & & 1 \\
\hline Melese paranensis Dognin, 1911 & & & & & & & 1 & & & & & 2 & 3 \\
\hline Napata jynx (Geyer, 1832) * & & & & & & & & 1 & & & & & 1 \\
\hline Paracles fusca (Walker, 1856) * & & 1 & & & & & & & & & & & 1 \\
\hline Paracles sp. & & 1 & & & & & & & & & & & 1 \\
\hline Pareuchaetes aurata (Butler, 1875) & 1 & 1 & 5 & 3 & 8 & 9 & 2 & 7 & & 1 & & & 37 \\
\hline Pheia albisigna (Walker, 1854) & & 1 & & & & & & 1 & & & 1 & & 3 \\
\hline Pheia haemapleura Hampson, $1914 \dagger$ & & & & & & 1 & 2 & & & & & 1 & 4 \\
\hline Pheia haematosticta Jones, 1908 & & & & & & & 1 & & & & 1 & 1 & 3 \\
\hline Pheia seraphina (Herrich-Schäffer, 1854) † & & & 3 & & & & & & & & 5 & 3 & 11 \\
\hline Phoenicoprocta baeri Rothschild, $1911 \dagger$ & & & & & & & 1 & & & & & & 1 \\
\hline Pseudalus limonia Schaus, $1896 \dagger$ & & 1 & & & & & & & & 1 & 1 & & 3 \\
\hline Pseudalus salmonaceous (Rothschild, 1909) * & & & & & & & & & & & 2 & & 2 \\
\hline Psychophasma erosa (Herrich-Schäffer, [1858]) * & & & & & 1 & & & & & & & & 1 \\
\hline Symphlebia abdominalis (Herrich-Schäffer, [1855]) & 1 & 1 & & & & & & 1 & & & 1 & & 4 \\
\hline Tipulodes ima Boisduval, 1832 * & & & & & 1 & & & & & & & & 1 \\
\hline Thrinacia temenus (Stoll, 1781) * & & & & & & & & & & & 1 & & 1 \\
\hline Utetheisa ornatrix (Linnaeus, 1758) * & & & & & & & 1 & & & & & & 1 \\
\hline \multicolumn{14}{|l|}{ Lithosiini } \\
\hline Agylla sp. 1 * & 7 & 2 & & 6 & & & & & & & & & 15 \\
\hline Agylla sp. 2 * & & & & & & & & & & & 1 & & 1 \\
\hline Agylla sp. $3 \dagger$ & & & & & & & & & & 3 & & & 3 \\
\hline Agylla sp. 4 * & 2 & & & & & & & & & & & & 2 \\
\hline Barsinella mirabilis Butler, 1878 * & & 3 & 1 & 1 & & & & & & & & & 5 \\
\hline Cisthene sp. 1 * & & & & & & & & & 1 & & & & 1 \\
\hline Cisthene sp. $2 \dagger$ & & & & & & & 1 & & & & & & 1 \\
\hline Dolichesia rufa Schaus, 1899 * & & & & & & & 1 & & 2 & & & & 3 \\
\hline Eudesmia ruficollis Donovan, $1798 \dagger$ & & & & 2 & & & & & & & & & 2 \\
\hline Lamprostola hercyna Druce 1885 & & & 1 & & & 1 & & & & & & & 2 \\
\hline Lamprostola sp. * & & 1 & & & 4 & 2 & 5 & 3 & 10 & 6 & & & 31 \\
\hline Lycomorphodes strigosa (Butler, 1877) * & & & & & & & 3 & & & & & & 3 \\
\hline Nodozana coresa Schaus, 1896 & & & & & & & 2 & & 1 & 4 & 1 & & 8 \\
\hline Odozana domina (Schaus, 1896) * & & & & & & & 1 & & 2 & 2 & & & 5 \\
\hline Parablavia sadima (Schaus, 1896) $\dagger$ & 1 & & 3 & 61 & & & & & & & & 2 & 67 \\
\hline Zonoda dives Schaus, 1896 * & & 1 & & & & & & & & & 1 & & 2 \\
\hline Lithosiini sp. 1 * & & & 1 & & & & & & & & & & 1 \\
\hline Lithosiini sp. 2 & & 1 & & 2 & & 1 & 2 & & 11 & & & & 17 \\
\hline Lithosiini sp. $3 \dagger$ & & & & & & & 1 & & & & & & 1 \\
\hline Lithosiini sp. 4 & & & 5 & & & & & & 1 & 2 & & 1 & 9 \\
\hline
\end{tabular}


The monthly abundance of all species sampled in the Jardim Botânico de Brasília ranged from 21 to 83 individuals, with a peak in April (Fig. 1). However, this peak was caused by a single extremely abundant species, $P$. sadima, which alone accounted for 61 individuals in this month. Excluding this species, the monthly abundance ranged from 21 to 37 individuals, with three peaks: one in the early rainy season (October to November) and the other two in the dry season (May and July) (Fig. 2). The monthly species richness ranged from seven to 21 species. The months with the greatest richness were November (rainy season) and July (dry). The month with the lowest species richness was September. The majority of species $(80 \%)$ occurred for up to three months. D. lucetius exhibited the broadest temporal distribution and was sampled in 11 months.

The monthly abundance in the gallery forest ranged from 4 to 27 individuals (Fig. 3), with one abundance peak occurring in September and another in January. Monthly richness ranged from 4 to 10 species. The greatest richness in the gallery forest was recorded in October and February and the lowest in March, April, and June. The monthly abundance ranged from 1 to 26 individuals in the cerrado sensu stricto (excluding
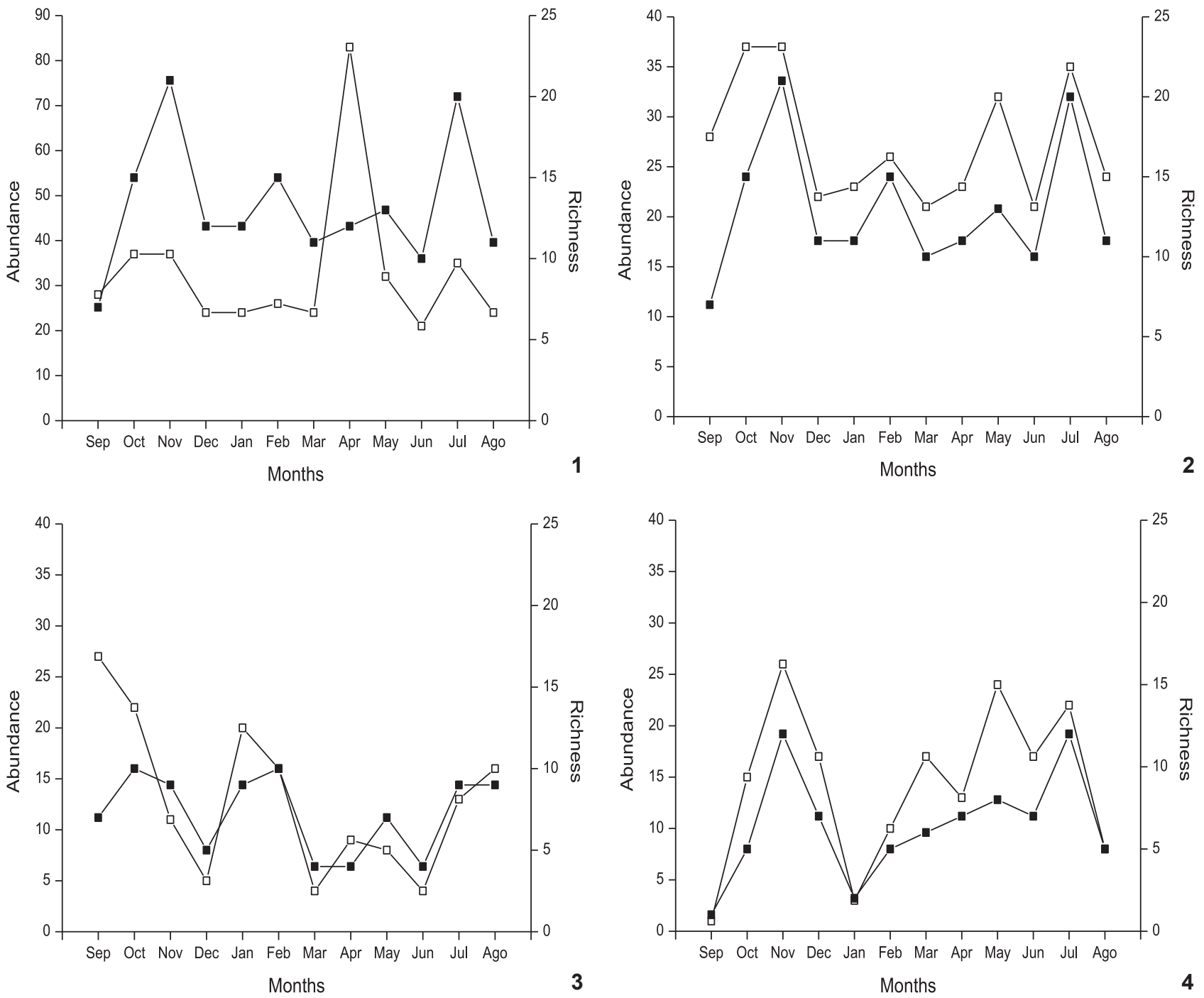

Figures 1-4. Species richness (black symbols) and abundance (white symbols) of Arctiinae moths throughout the year (September 2008 to August 2009) in a Cerrado area (Jardim Botânico de Brasília, Brasília, Brazil). The dry season is from April to September, and the rainy season is from October to March. (1) all species; (2) all species, except P. sadima; (3) gallery forest; (4) cerrado sensu stricto, excluding P. sadima. P. sadima occurred only in the cerrado sensu stricto and was extremely abundant in April, accounting for $73.5 \%$ of the individuals. 
P. sadima, Fig. 4) with four peaks: in November (early rainy season), March (end of rainy season), May (early dry season), and July (mid dry season). The monthly species richness ranged from 1 to 12 species. The months with the greatest richness in this vegetation type were November and July. The lowest richness and abundance were recorded in September and January. These months were associated with the highest abundance and richness in the gallery forest.

Circular analysis showed that the distribution of richness and abundance did not deviate from a uniform distribution (Table II), except for total abundance (including P. sadima) and abundance in the gallery forest. This result suggests that the tiger moths generally do not present a seasonal pattern.

\section{Species richness and abundance throughout the night}

The majority (80\%) of species were active for up to three hours during the night. Two species (D. lucetius and Lamprostola sp.) were sampled throughout the entire night. Hourly abundance varied from 24 to 50 individuals. Abundance was greater in the first two hours after dark, then decreased, and increased at the end of the night (Figs 5-7). Circular analysis showed that the abundance was concentrated $(\mathrm{r}=0.12, \mathrm{Z}=5.719, \mathrm{p}=0.003)$. Hourly richness ranged from 12 to 22 species. The hours of 7:00 pm and 8:00 pm were characterized by the greatest richness (21 and 22, respectively; Figs 5-7). However, the distribution of richness was dispersed throughout the night $(\mathrm{r}=0.069$, $\mathrm{Z}=0.864, \mathrm{p}=0.421$ ).

The distributions of abundance and richness in the gallery forest were similar to those of the overall fauna of the Jardim Botânico de Brasília (Figs 5-7). Abundance ranged from 6 to 31 individuals per hour and was uneven, with a greater number of sampled individuals being observed during the first two hours after dark $(\mathrm{r}=0.284, \mathrm{Z}=12.525, \mathrm{p}<0.001)$. The hourly richness ranged from 5 to 14 species. Although the first two hours were associated with greater richness (13 and 14, respectively), the richness distribution throughout the night was not aggregated $(\mathrm{r}=0.167, \mathrm{Z}=2.536, \mathrm{p}=0.079)$. Abundance ranged from 13 to 31 individuals, and richness ranged from 8 to 15 species per hour in the cerrado sensu stricto (Figs 5-7). The distribution of both richness and abundance was uniform throughout the night $(\mathrm{r}=0.067, \mathrm{Z}=1.092, \mathrm{p}=0.336$ for abundance; and $\mathrm{r}=0.048, \mathrm{Z}$ $=0.255, \mathrm{p}=0.775$ for richness).

\section{Annual and nightly species composition}

In general, the species composition differed between the dry and rainy seasons for the total set of species sampled (Fig. 8). The species composition in the first month of the rainy season (October) was similar to that of the dry season. Additionally, the species composition of the first months of the dry season (April) was similar to that of the rainy season. However, this pattern was not observed when the composition of each vegetation type was evaluated separately (Figs 9 and 10).

Compositional similarity also varied hourly. Two clusters were formed for all species and for those from the gallery forest: one composed mainly of species occurring in the first half of the night and another comprised mainly of species from the second half (Figs 11 and 12). There were no such groups detected for species in the cerrado sensu stricto (Fig. 13).

\section{DISCUSSION}

The study area is a well-preserved, 5,000-ha area. However, it is surrounded by degraded areas and roads and is heavily affected by city lights, which generally decreases sampling success when using light traps. Nevertheless, the richness of Arctiinae in the Jardim Botânico de Brasília can be considered high. The tiger moths in the reserve represent $9 \%$ of the 723 known species of Arctiinae in the Cerrado (Ferro et al. 2010), 5\% of the 1,391 known species in Brazil (Ferro \& Diniz 2010), and 1\% of the 5,931 Neotropical species (HeppNer 1991). An extensive study of the geographical distribution of 683 Arctiinae species (FERro

Table II. Rayleigh's uniformity test for abundance and richness of Arctiinae per vegetation type (gallery forest and cerrado sensu stricto) and in the Jardim Botânico de Brasília (total). The results of the analysis without $P$. sadima are also presented. Non-uniform distributions indicate that the data are concentrated around the mean; i.e., there is a seasonal pattern. A uniform distribution indicates the opposite.

\begin{tabular}{lcccc}
\hline & $\mathrm{r}$ & $\mathrm{Z}$ & $\mathrm{p}$ & Distribution \\
\hline Total abundance & 0.098 & 3.781 & 0.023 & Non-uniform \\
Total abundance without P. sadima & 0.080 & 2.112 & 0.121 & Uniform \\
Total richness & 0.040 & 0.258 & 0.773 & Uniform \\
Total richness without P. sadima & 0.045 & 0.312 & 0.732 & Uniform \\
Abundance in the cerrado sensu stricto & 0.311 & 23.240 & $<0.001$ & Non-uniform \\
Abundance in the cerrado sensu stricto without P. sadima & 0.081 & 1.136 & 0.321 & Uniform \\
Richness in the cerrado sensu stricto & 0.066 & 0.350 & 0.704 & Uniform \\
Richness in the cerrado sensu stricto without P. sadima & 0.081 & 0.511 & 0.600 & Uniform \\
Abundance in the gallery forest & 0.235 & 8.593 & $<0.001$ & Non-uniform \\
Richness in the gallery forest & 0.121 & 1.273 & 0.280 & Uniform \\
\hline
\end{tabular}



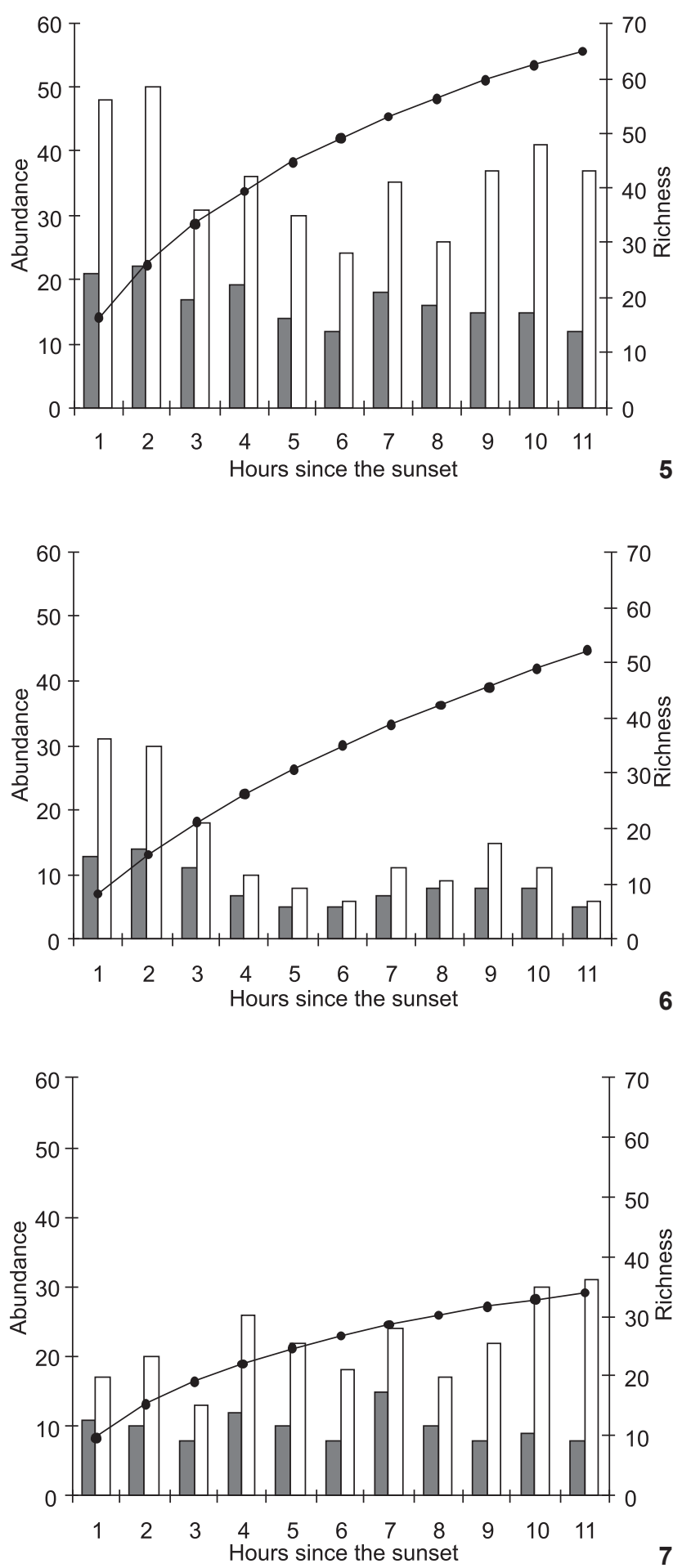

Figures 5-7. Observed richness (black bars), accumulated richness (line), and abundance (white bars) of Arctiinae moths throughout the night in a Cerrado area (Jardim Botânico de Brasília, Brasília, Brazil). (5) all species; (6) gallery forest; and (7) cerrado sensu stricto.
$\&$ DinIz 2010) found that only $2.3 \%$ of the species recorded for the Cerrado are endemic. This study detected the occurrence of three Cerrado endemic species in the Jardim Botânico de Brasília: Cosmosoma cruenta (Petry, 1834), Elysius joiceye Talbot, 1928, and Leucanopsis rosetta (Schaus, 1896). Except for one individual of L. rosetta, all of these species were collected in the cerrado sensu stricto. Five of the species collected constitute new records for the Federal District and two are also new records for the Cerrado. The number of new species may be even greater given that there were 15 morphospecies identified only to the genus level and four at only the tribe level.

Few species were abundant (more than 15 individuals were collected for only eight species). In addition, singletons accounted for $38.5 \%$ of the species. These results represent a common pattern for both adults and larvae of Lepidoptera in the Tropics, including the Cerrado (e.g., Price et al. 1995, DinIz \& Morais 1997, Camargo 1999, Marquis et al. 2002, Gusmão \& Creão-Duarte 2004, Ferro \& Diniz 2007, Scherrer et al. 2010).

Most of the abundant species (six out of eight species with more than 15 individuals) occurred in both vegetation types, but with quite different abundances. For example, $D$. lucetius and $P$. aurata were more abundant in the cerrado sensu stricto ( $87 \%$ and $84 \%$ of individuals, respectively). In contrast, Lamprostola sp. was more abundant in the gallery forest $(65 \%$ of individuals), suggesting that even common species prefer specific habitats. Parablavia sadima, the most abundant species, occurred only in the cerrado sensu stricto and accounted for $28 \%$ of all individuals collected in this formation. This result could explain the higher dominance and abundance found in the cerrado sensu stricto than in the gallery forest.

In this study, more species were restricted to gallery forest $(47.7 \%)$ than to the cerrado sensu stricto (20\%). This result supports the key role of the gallery forest in the maintenance of biodiversity and on the conservation of the tiger moths and other lepidopterans of the Cerrado (CAmargo 2001, Brown \& GifFord 2002). Furthermore, the gallery forest areas harbor a higher species richness of Arctiidae than the cerrado sensu stricto during the dry season. This result corroborates the argument of BRown $J_{R}(2004)$ that the gallery forests serve as a refuge for insect fauna during the dry season. The use of gallery forests as a refuge is also common among amphibians and reptiles (Colli et al. 2002), birds (MACEDo 2002), and mammals (GALeTTI et al. 2010).

The gallery forest is less affected by the effects of the dry season than the cerrado sensu stricto (Oliveira-Filho \& Ratter 2002). Additionally, the gallery forest vegetation is more similar to the Atlantic Forest (55\%) than to the Cerrado vegetation (Oliveira-Filho \& Ratter 1995). Therefore, we expected that the temporal dynamics differed between these two vegetation types (e.g. there was less variation in richness and abundance in the gallery forest than in the cerrado sensu stricto because its climate is more stable during the year or due to differences in vegetation). Although differences were observed in relation to temporal dynamics in the gallery forest and cerrado sensu stricto, 

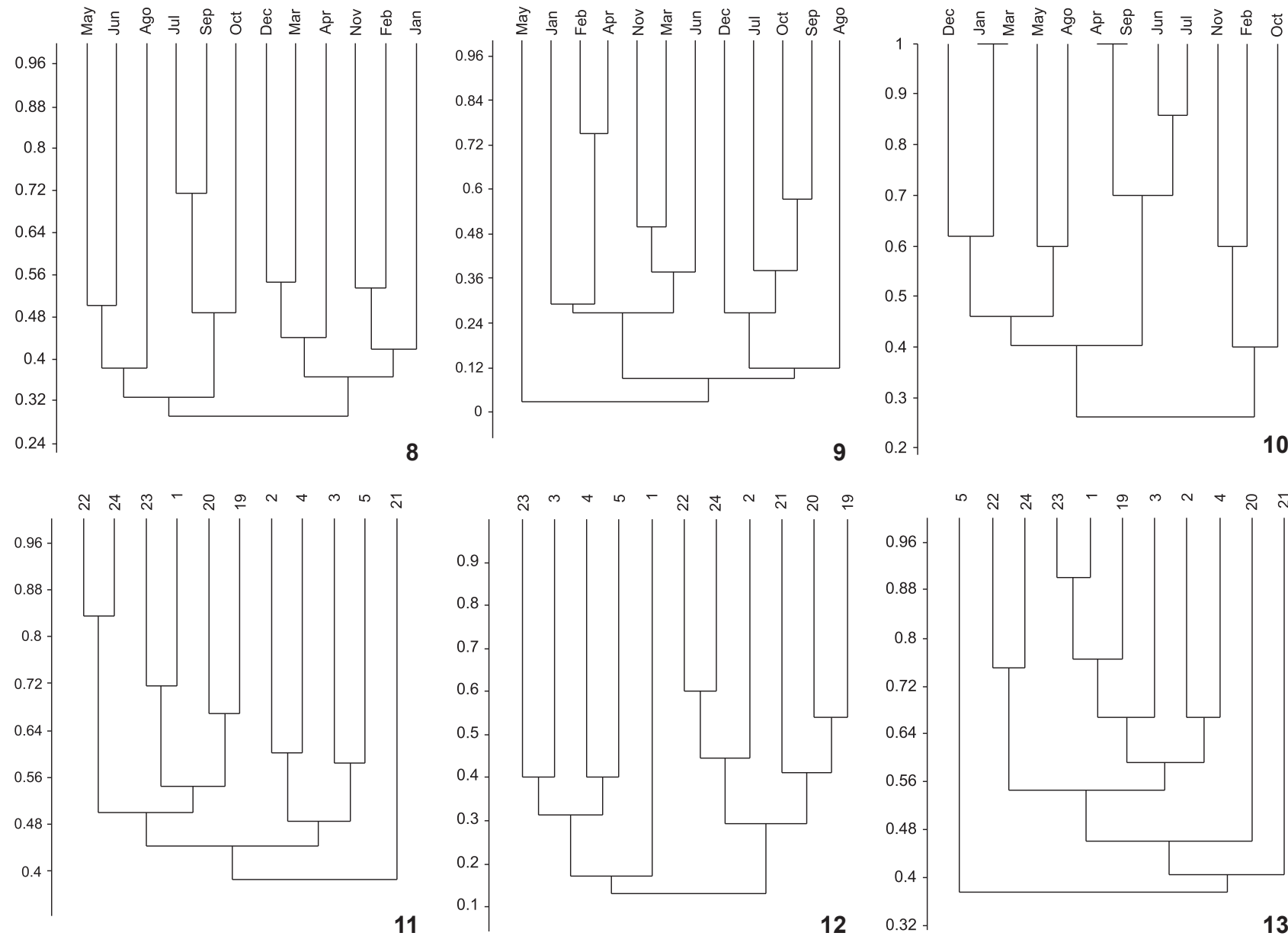

Figures 8-13. Similarity in the composition of Arctiinae moths across months (8-10) and during the hours of the night (11-13) in a Cerrado area (Jardim Botânico de Brasília, Brasília, Brazil). Clustering performed by UPGMA, using Simpson similarity index as distance measure. (8) all species; (9) gallery forest; (10) cerrado sensu stricto; (11) all species; (12) gallery forest; and (13) cerrado sensu stricto (correlation coefficients $0.560,0.787,0.632,0.747,0.749$, and 0.790 , respectively). Numbers on the left are values for Simpson's similarity index. The dry season is from April to September, and the rainy season is from October to March.

unfortunately we are unable to explore the factors that explain these variations in the peaks of abundance and species richness during the night as well as annually due to the methodology used in this work and the lack of replicates of our data.

Although the sampling in the rainy season was representative of most species, the lack of sampling in the dry season would represent a loss of $31 \%$ of the species. Thus, annual collections (BitTencourt et al. 2003, Teston \& Corseuil 2004, DuarteJúnior \& Schlindwein 2005, Amorim et al. 2009, Teston \& Delfina 2010) are more effective for capturing species richness than those performed only in the rainy season (SевсHт et al. 2005, FERRo \& DinIz 2007, Hawes et al. 2009). Similarly, increasing the intervals between nocturnal sampling would cause an increase of species sampled. For example, if the samplings were restricted to the first five hours of the night (from 7:00 pm to midnight), only $55 \%$ of the individuals and $70 \%$ of the total species would have been recorded. Abundance would drop to $32 \%$ and richness to $54 \%$ if the samplings were restricted to the first two hours after dark. Thus, we suggest that future rapid assessments or surveys of nocturnal Lepidoptera should be performed throughout the entire night, as in previous studies (BITTENCOURT et al. 2003, Duarte Júnior \& SChlindwein 2005, Амorim et al. 2009, HAWEs et al. 2009).

This study showed that the species composition of Arctiinae associated with gallery forests and cerrado sensu stricto in the Jardim Botânico de Brasília is quite different. The species composition also varies throughout the year and night. This study also found differences in activity throughout the night and provides a better understanding of the community dynamics of tiger moths in the region. Based on our findings, we sug- 
gest changes in the methodology used for rapid inventories, in which samplings of tiger moths must be performed in both rainy and dry seasons as well as the throughout the entire night. This work also supports the suggestion made by other authors (HiLT et al. 2007) that the sampling of moths should preferably include several periods of the year to account for the seasonal variation in the species composition in different habitats.

\section{ACKNOWLEDGMENTS}

We would like to thank Vitor O. Becker for his critical help in Arctiinae species identification. Vanessa Staggemeier helped with the circular analysis. Felipe Brito helped in the fieldwork. Ivan Molinov, Dheivid Pereira, and Kaio Farias mounted the insects. IBAMA provided the collecting permits. We would also like to thank the staff and researchers of the Jardim Botânico de Brasília for permission to carry out the research and logistical support. Marina Neis was supported by a Scientific Initiation fellowship from CNPq/UnB. FAPDF/PRONEX provided additional funding. Ivone Diniz is a CNPq fellow.

\section{LITERATURE CITED}

Amorim, F.W.; R.S. Ávila Jr; A.J.A. Camargo; A.L. Vieira \& P.E. Oliveira. 2009. A hawkmoth crossroads? Species richness, seasonality and biogeographical affinities of Sphingidae in a Brazilian Cerrado. Journal of Biogeography 36: 662-674.

Araújo, C.S.; D.M. Candido; H.F.P. Araújo; S.C. Dias \& A. VASCONCELLOS. 2010. Seasonal variations in scorpion activities (Arachnida: Scorpiones) in an area of Caatinga vegetation in northeastern Brazil. Zoologia 27 (3): 372-376.

Araújo, W.S. \& B.B. Santos. 2009. Efeitos da sazonalidade e do tamanho da planta hospedeira na abundância de galhas Cecidomyiidae (Diptera) em Piper arboreum (Piperaceae). Revista Brasileira de Entomologia 53 (2): 300-303.

Axmacher, J.C.; G. Brehm; A. Hemp; H. Tunte; H.V.M. Lyaruu; K. Muller-Hohenstein \& K. Fiedler. 2009. Determinants of diversity in afrotropical herbivorous insects (Lepidoptera: Geometridae): plant diversity vegetation structure or abiotic factors? Journal of Biogeography 36: 337-349.

Beck, J.; C.H. Schulze; K.E. Linsenmair \& K. Fiedler. 2002. From forest to farmland: diversity of geometrid moths along two habitat gradients on Borneo. Journal of Tropical Ecology 18: 33-51.

Bittencourt, M.A.L.; L. Boaretto; I. Serafim \& E. Berti Filho. 2003. Fauna de Lepidoptera associada a um ecossistema natural no estado de São Paulo. Arquivos do Instituto Biológico 70 (1): 85-87.

Brehm, G.; J. Homeier \& K. Fiedler. 2003. Beta diversity of geometrid moths (Lepidoptera: Geometridae) in an Andean montane rainforest. Diversity and Distributions 9: 351366.

BRown JR, K.S. \& D.R. GIFFord. 2002. Lepidoptera in the cerrado landscape and the conservation of vegetation, soil and topographical mosaics, p. 201-217. In: P.S. OliveIRA \& R.J. MARQUIS (Eds). The cerrado of Brazil: ecology and natural history of a neotropical savanna. New York, Columbia University Press, 398p.

BROWN JR, K.S. 2004. Insetos indicadores da história, composição, diversidade e integridade de matas ciliares, p. 223-232. In: R.R. Rodrigues \& H.F. Leitão Filho (Eds). Matas ciliares, conservação e recuperação. São Paulo, Edusp, 320p.

CAMARgo, A.J.A. 1999. Estudo comparativo sobre a composição e a diversidade de lepidópteros noturnos em cinco áreas da Região dos Cerrados. Revista Brasileira de Zoologia 16 (2): 369-380.

CAmargo, A.J.A. 2001. Importância das Matas de Galeria para a conservação de lepidópteros do Cerrado, p. 607-634. In: J.F. Ribeiro; C.E.L. Fonseca \& J.C. Sousa-Silva (Eds). Cerrado: caracterização e recuperação de Matas de Galeria. Planaltina, Embrapa - CPAC, 899p.

Colli, G.R.; R.P. Bastos \& A.F.B. Araújo. 2002. The character and dynamics of the cerrado herpetofauna, p. 223-241. In: P.S. Oliveira \& R.J. Marquis (Eds). The cerrado of Brazil: ecology and natural history of a neotropical savanna. New York, Columbia University Press, 398p.

Cook, L.M. \& C.S. Graham. 1996. Evenness and species number in some moth populations. Biological Journal of the Linnean Society 58: 75-84.

Diniz, I.R. \& H.C. MoRaIs. 1997. Lepidopteran Caterpillar fauna of cerrado host plants. Biodiversity and Conservation 6: 817-836.

Duarte Júnior, J.A. \& C. SChlindwein. 2005. Riqueza, abundância e sazonalidade de Sphingidae (Lepidoptera) num fragmento de Mata Atlântica de Pernanbuco, Brasil. Revista Brasileira de Zoologia 22 (3): 662-666.

Dyer, L.A.; M. S. Singer; J.T. Lill; J.O. Stireman; G.L. Gentry; R.J. Marquis; R.E. Ricklefs; H.F. Greeney;D.L. Wagner; H.C. Morais; I. R. Diniz; T.A. Kursar \& P.D. Colley. 2007. Host specificity of Lepidoptera in tropical end temperate forests. Nature 448: 696-700.

Ferro, V.G. \& I.R. Diniz. 2007. Composição de espécies de Arctiidae (Insecta, Lepidoptera) em áreas de Cerrado. Revista Brasileira de Zoologia 24 (3): 635-646.

Ferro, V.G. \& I.R. Diniz. 2010. Riqueza e composição de mariposas Arctiidae (Lepidoptera) no cerrado, p. 257-313. In: I.R. Diniz; J. Marinho Filho; R.B. Machado \& R.B. Cavalcanti (Eds). Cerrado: conhecimento científico quantitativo como subsídio para ações de conservação. Brasília, Editora Thesaurus, 516p.

Ferro, V.G.; A.S. Melo \& I.R. Diniz. 2010. Richness of tiger moths (Lepidoptera: Arctiidae) in the Brazilian Cerrado: how much do we know? Zoologia 27 (5): 725-731.

Fonseca, M.S. \& M.C. Silva Júnior. 2004. Fitossociologia e similaridade florística entre trechos de Cerrado sentido restrito em interflúvio e em vale no Jardim Botânico de Brasília, DF. 
Acta Botanica Brasilica 18 (1): 19-29.

Galetti, M.; R. Pardini; J.M.D. Barbanti; V.M.F. Silva; A. Rossi \& C.A. Peres. 2010. Mudança no código florestal e seu impacto na ecologia e diversidade dos mamíferos no Brasil. Biota Neotropica 10 (4): 47-52. Available online at: http:// www.biotaneotropica.org.br/v10n4/pt/fullpaper?bn007100 42010+pt [Accessed: 4/V/2012].

Gusmão, M.A.B. \& A.J. Creão-Duarte. 2004. Diversidade e análise faunística de Sphingidae (Lepidoptera) em área de brejo e caatinga no estado da Paraíba, Brasil. Revista Brasileira de Zoologia 21 (3): 491-498.

Hammer, Ø; D.A.T. Harper \& P.D. Ryan. 2007. PAST PAlaeontological STatistics. Available online at: http:// folk.uio.no/ohammer/past [Accessed: 4/V/2012].

Hawes, J.; C.S. Motta; W.L. Overal; J. Barlow; T.A. Gardner \& C.A. Peres. 2009. Diversity and composition of Amazonian moths in primary, secondary and plantation forests. Journal of Tropical Ecology 25: 281-300.

Heppner, J.B. 1991. Faunal regions and the diversity of Lepidoptera. Tropical Lepidoptera 2 (Suppl. 1): 1-85.

Hilt, N. \& K. FiedLer. 2005. Diversity and composition of Arctiidae moth ensembles along a successional gradient in the Ecuadorian Andes. Diversity and Distributions 11: 387-398.

Hilt, N.; G. BRehm \& K. Fiedler. 2007. Temporal dynamics of rich moth ensembles in the montane forest zone in Southern Ecuador. Biotropica 39 (1): 94-104.

Kitching, R.L.; A.G. OrR; L. Thalib; H. Mitchell; M.S. Hopkins \& A.W. Graham. 2000. Moth assemblages as indicators of environmental quality in remnants of upland Australian rain forest. Journal of Applied Ecology 37: 284-297.

Kovach Computing Services. 2011. Oriana version 3. Available online at: http://www.kovcomp.com/index.html [Accessed: $4 / \mathrm{X} / 2011]$.

Macedo, R. 2002. The avifauna: ecology, biogeography, and behavior, p. 242-263. In: P.S. Oliveira \& R.J. Marquis (Eds). The cerrado of Brazil: ecology and natural history of a neotropical savanna. New York, Columbia University Press, 398p.

Marquis, R.J.; H.C. Morais \& I.R. DinIz. 2002. Interactions among cerrado plants and their herbivores: unique or typical?, p. 306-328. In: P.S. Oliveira \& R.J. Marquis (Eds). The cerrado of Brazil: ecology and natural history of a neotropical savanna. New York, Columbia University Press, 398p.

Mineo, M.F.; K. Del-Claro \& A.D. Brescovit. 2010. Seasonal variation of ground spiders in a Brazilian Savanna. Zoologia 27 (3): 353-362.

Morais, H.C.; I.R. Diniz \& D.M.S. Silva. 1999. Caterpillar seasonality in a central Brazilian cerrado. Revista de Biologia Tropical 47: 1025-1033.

Novotny, V.; S.E. Miller; J. Hulcr; R.A. Drew; Y. Basset; M. Janda; G.P. Setliff; K. Darrow; A.J.A. Stewart; J. Auga; B. Isua; K. Molem; M. Manumbor; E. Tamtiai; M. Mogia \& G.D. Weiblen. 2007. Low beta diversity of herbivorous insects in tropical forests. Nature 448: 692-695.

Oliveira, C.M. \& M.R. Frizzas. 2008. Insetos do Cerrado: distribuição estacional e abundância. Boletim de pesquisa e desenvolvimento. Planaltina, Embrapa - CPAC, 22p.

Oliveira-Filho, A.T. \& J.A. Ratter. 1995. A study of the origin of central Brazilian forests by the analysis of plant species distribution patterns. Edinburgh Journal of Botany 52: 141-194.

Oliveira-Filho, A.T. \& J.A. Ratter. 2002. Vegetation physiognomies and woody flora of the Cerrado Biome, p. 91-120. In: P.S. OlIVEIra \& R.J. MARQUis (Eds). The cerrado of Brazil: ecology and natural history of a neotropical savanna. New York, Columbia University Press, 398p.

Pinheiro, F.; I.R. Diniz; D. Coelho \& M.P.S. Bandeira. 2002. Seasonal pattern of insect abundance in Brazilian cerrado. Austral Ecology 27: 132-136.

Price, P.W.; I.R. Diniz; H.C. Morais \& E.S.A. Marques. 1995. The abundance of insect herbivore species in the tropics: the high local richness of rare species. Biotropica 27 (4): 468-478.

Ratter, J.A.; J.F Ribeiro \& S. Bridgewater. 1997. The Brazilian cerrado vegetation and threats to its biodiversity. Annals of Botany 80: 223-230.

Sambuichi, R.H.R. \& G. Eiten. 2000. Fitossociologia da camada lenhosa de um cerrado em Brasília, DF. Boletim do Herbário Ezechias Paulo Heringer 5: 62-87.

SCherrer, S.; I.R. Diniz \& H.C. Morais. 2010. Climate and host plant characteristic effects on lepidopteran catterpillar abundance on Miconia ferruginata DC. and Miconia pohliana Cogn (Melastomataceae). Brazilian Journal of Biology 70 (1): 103-109.

Schwartz, G. \& R.A. Di Mare. 2001. Diversidade de quinze espécies de borboletas (Lepidoptera, Papilionidae) em sete comunidades de Santa Maria, RS. Ciência Rural 31: 49-55.

Sinvonen, P. \& M. Silijander. 2005. Species diversity and geographical distribution of Scopulini moths (Lepidoptera: Geometridae, Sterrhinae) on a world-wide scale. Biodiversity and Conservation 14: 703-721.

Silva, N.A.P.; M.R. Frizzas \& C.M. Oliveira. 2011. Seasonality in insect abundance in the "Cerrado" of Goiás State, Brasil. Revista Brasileira de Entomologia 55 (1): 79-87.

Silveira Neto, S.; R.C. Monteiro; R.A. Zucchi \& R.C.B. Moraes. 1995. Uso da análise faunística de insetos na avaliação do impacto ambiental. Scientia Agricola 52 (1): 9-15.

Specht, A.; J.A. Teston; R.A. Di Mare \& E. Corseull. 2005. Noctuídeos (Lepidoptera, Noctuidae) coletados em quatro áreas estaduais de conservação do Rio Grande do Sul, Brasil. Revista Brasileira de Entomologia 49 (1): 130-140.

Sousa, W.O.; M.I. Marques; G.H. Rosado-Neto \& J. Adis. 2007. Surface swimming behavior of the curculionid Ochetina uniformis Pascoe (Erirhininae, Stenopelmini) and Ludovix fasciatus (Gyllenhal) (Curculioninae, Erodiscini). Revista Brasileira de Entomologia 51 (1): 87-92.

Summerville, K.S.; L.M. RitTer \& T.O. CRisT. 2004. Forest moth taxa as indicators of lepidopteran richness and habitat disturbance: a 
preliminary assessment. Biological Conservation 116: 9-18.

Teston, J.A. \& E. Conseuil. 2004. Diversidade de Arctiinae (Lepidoptera, Arctiidae) capturados com armadilha luminosa, em seis comunidades no Rio Grande do Sul, Brasil. Revista Brasileira de Entomologia 48 (1): 77-90.

Teston, J.A. \& M.C. Delfina. 2010. Diversidade de Arctiinae (Lepidoptera, Arctiidae) em áreas alterada em Altamira, Amazônia Oriental, Pará, Brasil. Acta Amazônica 40 (2): 387-396.

Vasconcellos, A.; R. Andreazze; A.M. Almeida; H.F.P. Araújo; E.S.

Submitted: 08.V.2012; Accepted: 30.X.2012.

Editorial responsibility: Kleber Del Claro
Oliveira \& U. Oliveira. 2010. Seasonality of insects in the semi-arid Caatinga of Northeastern Brazil. Revista Brasileira de Entomologia 54 (3): 471-476.

Wolda, H. 1978. Seasonal flutuation in rainfall, food and abundance of tropical insects. Journal of Animal Ecology 47: 369-381.

Wolda, H. 1988. Insect seasonality: Why? Annual Review of Ecology and Systematics 19: 1-18.

ZAR, J.H. 1996. Biostatistical analysis. New Jersey, PrenticeHall, $3^{\text {rd }}$ ed., 662p. 